\section{OUR COLLECTIVE NARRATIVE WAS BEING CONSTRUCTED IN THE FILM PRODUCTION. A CONVERSATION AT THE CROSSROADS BETWEEN MILITANTS, MEDIA PRODUCTION AND RESEARCH}

\author{
Elisabet Cerqueira da Conceição \\ MST national coordination (Brazil) \\ ORCID: 0000-0002-8644-7836 \\ elizapubli@gmail.com
}

\begin{abstract}
NUESTRA NARRATIVA COLECTIVA SE ESTABA CONSTRUYENDO EN LA PRODUCCIÓN CINEMATOGRÁFICA. UNA CONVERSACIÓN EN LA ENCRUCIJADA ENTRE LOS MILITANTES, LA PRODUCCIÓN MEDIÁTICA Y LA INVESTIGACIÓN
\end{abstract}

\author{
Luiz Enrique Gomes de Moura \\ MST national coordination (Brazil) \\ ORCID: 0000-0001-6077-6714 \\ zarref@gmail.com
}

\author{
Paola Sartoretto \\ Jönköping University (Sweden) \\ ORCID: 0000-0002-5638-6606 \\ paola.sartoretto@ju.se
}

Para citar este artículo:

Cerqueira da Conceição, E., Gomes de Moura, L.E., Freitas, C. \& Sartoretto, P. (2020). Our collective narrative was being constructed in the film production. A conversation at the crossroads between militants, media production and research. Commons. Revista de Comunicación y Ciudadanía Digital, 9(2), 186-210. http://doi.org/10.25267/COMMONS.2020.v9.i2.06

Fecha de recepción: 10/05/2020. Fecha de aceptación: 02/07/2020

\begin{abstract}
This text is based on a conversation between members in the Brazilian Landless Workers Movement, a film producer and a media and communication researcher about the production process of the documentary Chão (Landless). Chão documents MST's processes of land occupation and the battles to gain rights to land in the state of Goiás between 2014 and 2018. MST's mobilization practices since the emergence of the Movement in 1984 have been much informed by Paulo Freire's emancipatory pedagogy. The Movement's historically situated social action constructs knowledge about reality at the same time that it changes reality. The documentary is an example of participatory media production in which the filmmaker and the militants constructed a narrative together from their different perspectives. This participatory process is used here as a departure point to discuss the experiential dynamics of the conscientization process from the different perspectives of research, media production, and militancy.
\end{abstract}

\section{Keywords}

MST, Brazil, social movements, Chão

\section{Resumen}

Este texto se basa en una conversación entre miembros del Movimiento de Trabajadores sin Tierra de Brasil (MST), una directora de cine y una investigadora en comunicación sobre el proceso de producción del documental Chão (Landless). Chão documenta los procesos de ocupación de tierras del MST y las luchas para conseguir derechos sobre la tierra en el estado de Goiás entre 2014 y 2018. Las prácticas de movilización del MST desde el surgimiento del Movimiento en 1984 han estado muy influidas por la pedagogía emancipadora de Paulo Freire. La acción social históricamente situada del Movimiento construye conocimiento sobre la realidad al mismo tiempo que la cambia. El documental es un ejemplo de producción de medios participativos en el que el cineasta y los militantes construyeron juntos una narrativa desde sus diferentes perspectivas. Este proceso participativo se usa aquí como punto de partida para discutir la dinámica experiencial del proceso de concientización desde las diferentes perspectivas de investigación, producción de medios y militancia.

\section{Palabras clave}

MST, Brasil, movimientos sociales, Chão 


\section{Conscientization and media production: from world reading to world writing}

Paulo Freire became known in Brazil in the 1960s for his method of adult alphabetization in which learners are educated to become autonomous social subjects that should learn to read the word in order to be able to read the world. By autonomously reading the word and the world workers could become social subjects able to overcome the conditions of oppression in which they find themselves. Many popular collectives and social movements working with education in Brazil adopted and developed Freirean pedagogy to create, among their constituencies, the conditions for this critical reading and apprehension of the world, or conscientization in Freire's terminology. The Landless Workers Movement (MST) in Brazil is among the collectives that adopted Freirean pedagogies in their educational work, which has the objective to form subjects to engage in the struggle against oppression. We can also argue that MST, with their collectively developed educational practice, has taken Freirean methodologies to a further level, teaching Landless subjects to write the world, to objectify and concretize pre-figurative political imaginaries into art, poetry, politically engaged journalism, and film. The documentary Chão ${ }^{1}$ (Landless in the English title), directed by Camila Freitas is an example of world writing. The documentary takes the viewer into the concrete reality of the struggle for land in the state of Goiás, in central Brazil. Chão was released in 2019 after almost five years of collective production. Shooting started in the end of 2014, in the interstice between the protests of June 2013 and the impeachment of President Dilma Rousseff in 2016.

\footnotetext{
1. In Portuguese Chão can mean ground or soil. This title symbolizes the strong relation that rural workers establish with the territory where they live and work, which is the ground where they build their lives, the concrete object of their struggle for agrarian reform, and also their means of subsistence. I have chosen to use the Portuguese title throughout the text, instead of the English title Landless, in order not to confuse with the word "Landless" used to refer to the collective and individual Landless subjects. I am here making a conscious choice not to use the English translated title, following Freire who has always been critical to translations that do not capture the original and full meaning of words. He was knowingly against the translation of conscientização to conscientization and has reportedly stated "I do not have to accept stress, but I have. Why do you not accept conscientização?" [italics in the original] (Macedo, 2018). See MACEDO, D. (2018). Introduction to Pedagogy of the Oppressed. In FREIRE, P. Pedagogy of the Oppressed - 50th Anniversary Edition (M. Bergman Ramos, Trans.) (pp. 11-27). New York: Continuum.
} 
If it would be possible to repurpose Freire's terminology to media production, we could say that the production of Chão refused banking processes in which documentary producers collect material in form of interviews, documents, footage, and deliver a product in form of media content, usually following a strict production schedule. Freire has many times expressed criticism toward commercial media in Brazil, particularly the inability of commercial media to produce or foster social critique and the oblivion to questions relevant to the working class. However, the end of the civil-military dictatorship in Brazil coupled with technological development that made communication technologies more accessible to popular collectives created opportunities for the appropriation of media by these collectives that are able to subvert the objectifying logics of commercial media. Freire passed in 1997 and did not live to see the exponential growth of community and alternative media that produce counter-hegemonic content in Brazil and Latin America.

The role of intellectuals, researchers and research as praxis that dialectically relates theory and practice is prominent in Freire's work. He defended that intellectuals and scholars should become comrades (acompanheirar-se) with the oppressed, but always recognising the different perspectives, without attempting to impose on or lead but to critically engage in the struggle as allies. It is not easy to live up to these principles in a historical period when the neoliberal ethos underpins all social relations. Researchers and media producers need to generate outputs, we are immersed in market relations and the market is many times within us.

Chão is the evidence that it is possible to challenge and refuse to reproduce predatory relations with social movements. From the perspective of media and communication research, this kind of production process is interesting in two different dimensions: as an object of analysis to discuss the possibilities and practices of participatory communication and as an exemplary experience to inspire participatory and socially engaged research. This is the background for a conversation with Bete Cerqueira da Conceição and Luiz Enrique Gomes de Moura from MST in Goiás, who have participated in the production and post- 
production of Chão, and filmmaker Camila Freitas, in which we discuss the grounded experiences of this intersection between the practices of research, media production and social mobilization.

\section{Crossing Paths}

Paola: I would like for us to start by talking about how the different paths and practices of media production, militancy and researcher intersect.

Luiz: The dynamics of the struggle for land teaches us that it is crucial to build networks of support and solidarity from the moment we occupy land and organize a settlement. When we occupy a large property to denounce that agrarian reform is not being carried through, to claim that the property must be destined to agrarian reform, we always seek channels for dialogue with society to create the conditions for dialogue among the Landless families and to build solidarity to protect us from violent repression. In the case of the film Chão, we portray a specific period of the struggle for land in the state of Goiás. In previous years we had faced difficulties in the struggle for land in the state. What happened on the 31st of August 2014 is the outcome of six months of grassroots work in the peripheries of the urban centres in that region. This mobilization was itself an outcome of the popular protests in June 2013. In the state of Goiás, we evaluate what happened in June of 2013 as an indicative that the situation for the working class in urban centres was becoming untenable. Salaries were low, unemployment and violence were growing. We encountered much interest among the families when presented the struggle for land. We took this opportunity and carried out this grassroots work.

We occupied Santa Monica farm on the 31st of August in 2014 with over three thousand families. It is the biggest occupation in Goiás' recent history and it happened in a period when the hegemony of agribusiness had removed agrarian reform from the public debate. This particular occupation generated much interest not only from traditional political actors such as parties and unions, but also from universities, artists, and professionals working with community health and popular pedagogy. The occupation turned into a large laboratory for the exchange 
of technical knowledge about agroecology, with audio-visual production. In this process we met a number of media activists, from alternative and popular media outlets and also artists in the fields of audio-visual and theatre. And then we found this short documentary called Passarim about that territory. The documentary gave many new insights, because there is a pact of silence in that region about the Santa Monica complex. The Santa Monica complex consists of tens of farms that were incorporated by senator Eunício Oliveira through the encroachment of the rural workers who lived there. In that area there were previously many small and middle-sized family properties whose owners were gradually expelled, through economic and coercive pressure. Even in the grassroots work people were reluctant to talk about what had happened in that region and Passarim brings up these aspects. After watching the documentary we went searching for its producers and found Camila Freitas.

Camila: It was very interesting when this happened because I made Passarim when I was nineteen years old. I was at university. It is my first film. It is a very personal movie because despite not having peasant origins myself, my family lives in that region, my uncle and my cousins are rural producers. I lived in a nearby little town with my mother and brothers for ten years. I spent my childhood there and saw this landscape transforming, the whole region turning into these latifundia. Many people we knew, peasants who lived there, were being evicted. The main character in the movie is a craftsman who made wooden birds (passarim), hence the title. He was a friend of ours, I owned some of his wooden birds as a child. So that was not my reality, but I was very close to it and wanted to show it in the movie. But I had not quite imagined the dimension of the situation when I made the movie. Shortly after I finished it was shown at a university festival and after that it sat on a shelf. I had no idea about the political potential that this movie has by means of its dialogue about territory. What MST does is to try to understand and map out everything that exists in an occupied territory, because the struggle is not only to redistribute land, or to build a settlement. What are the sensibilities and the stories mobilized in each process of struggle?

So, Luiz called me. I didn't know him. It happened through an activist who was participating in this process that they started in the occupation. She was a friend of my mother who had seen Passarim. That moment was of great surprise because 
I was very interested in MST. I had tried before to make a movie with MST, we had a previous experience with people from Brasília University during a national event in 2001 that was never finished. It was already 2014 and Luiz called me and told me about the occupation, saying that they had occupied the Santa Monica complex with over three thousand families. For me this was excellent news at the personal level because I had witnessed some of the evictions and seen the landscape transforming in that region. In this call Luiz told me that my old film was important for this new occupation and this woke me up...

We started talking and I asked, "What is happening there?". Because of this framework of knowledge exchange that already existed there and MST's historical opening towards other fields to participate in processes of struggle, including communication and cinema, the movement was very receptive. Everything moved quite fast: the occupation happened at the end of August 2014, we met for the first time in September in Rio de Janeiro and stayed in contact. In December I was there in this occupation that was a real city, a world in itself, with a camera and a little crew, and without any funding.

\section{Walking a common path}

Paola: What happened in these four, five years until the film was released in 2019 ?

Camila: In 2014 we started filming without funding but with the support of the Movement. We started going to the occupation. First, I went by myself; then some friends came. Shortly after we applied for funding and received it in a moment of transition because the coup happened in 2016. This was the last opportunity for a film like this to be approved for production with public funding. We received funding in the beginning of 2016, but we had never stopped filming since 2014, we kept visiting the occupation. The collaboration was very intense between us in this period, it consolidated really in that moment, because the Movement quickly understood and embraced the proposal. Even before I could understand the film-project I was proposing. The Movement has a larger experience than mine 
in understanding the importance of alliances and networks for its survival and protection. I felt that Passarim worked as a presentation letter, it facilitated and brought up the common ground for us. It was then I met Bete, she was joining the movement and became an important interlocutor for us.

Paola: Bete, you appear a lot in the film and play an important role, with a strong presence. I'd like to ask you to tell us about this experience of being in the movie, seeing yourself on the screen and participating in the production.

\section{Image 1}

Santa Monica Complex, occupation Dom Tomás Balduíno

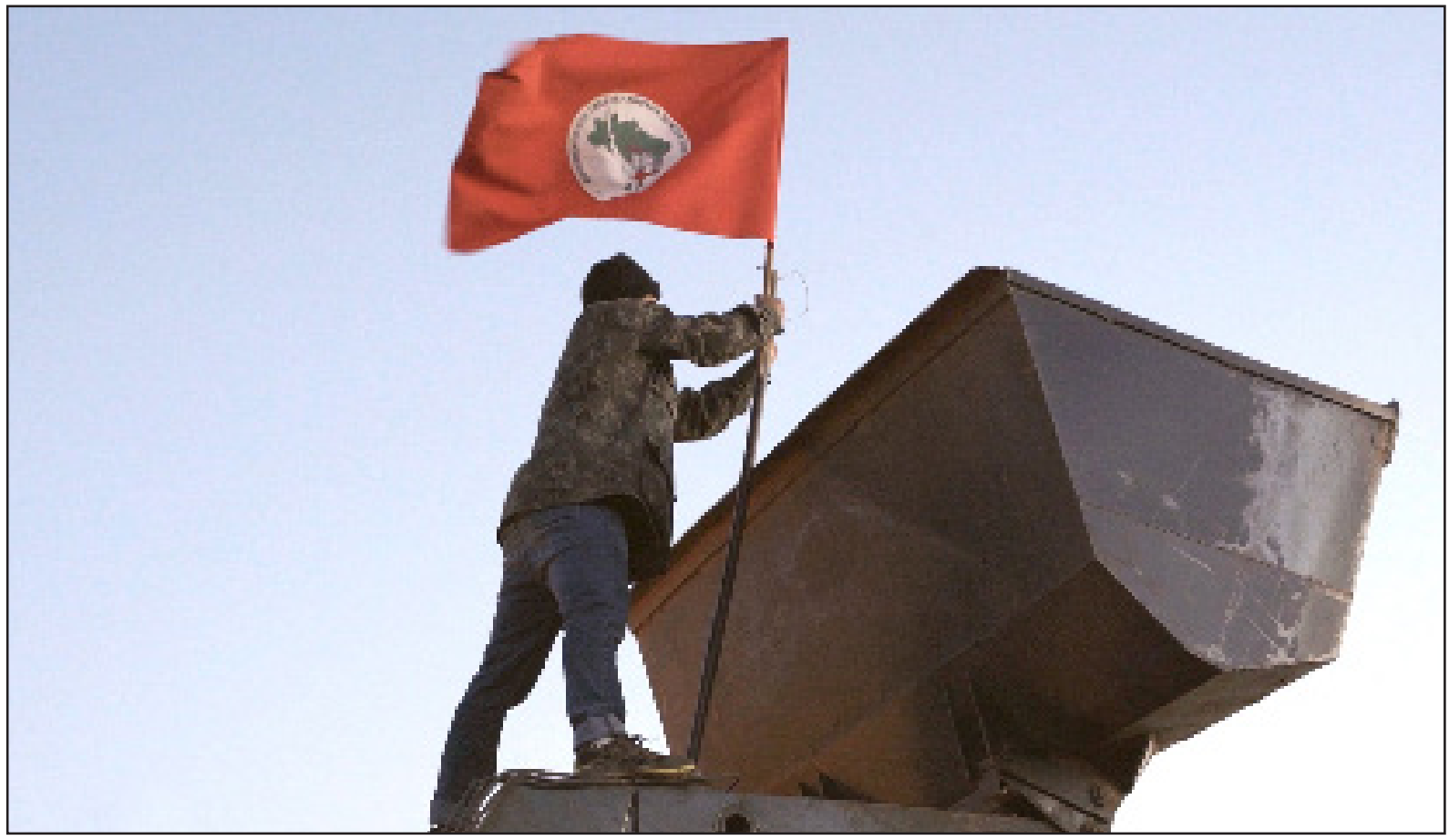

Photography: Camila Freitas

Bete: I joined MST in the preparation for the Santa Monica occupation. My life-story is a bit different but in the construction of an occupation we have to work collectively. This is the first shock if you come from a capitalist society, in which you have to fend for yourself. Life in the occupation gives you this lesson 
in collective living. Already in the beginning, one of the questions that is much emphasized among us who are occupying is the matter of studying and learning. Why do I mention studying and learning? Because this encounter we have with ourselves as Landless subjects is also the construction of our own narrative, this is what popular education and popular communication give us. We need not only to democratize land, democratize nature, but also democratize communication in order to transform society.

When Camila first came to talk about the movie, those of us in the leadership became a bit apprehensive because the narrative about the Movement is very much one of criminalization and victimization. We were forced to learn filmmaking collectively. We also had to make the movie without necessarily becoming a character, being ourselves, and this is difficult. For example, when you arrive at someone's home at lunchtime people must feel comfortable with a camera when your daily life is turned upside down. What I could notice in this sense is that we were also constructing the film, because we were always talking to Camila. We told her what was bothering us and what wasn't. This whole thing about the collective construction of narratives I think is what brings the work so close to us. Myself, as Bete, Landless subject who has been part of this struggle for a short time, I think this is the trigger of transformation, when you understand even this language that is so distant from us workers, because it is expensive for us to go to the cinema and to make cinema. But it is a transformative tool at the same time as it unites. We can see when Chão is shown in public, what the movie communicates, how it is so close to us and how even for those who do not know about the MST the movie translates in a very authentic way what it means to be Landless. There is another question in the movie. We learned gradually how to place a variety of subjects and characters in the movie. Of course, one or another is more prominent, but we don't see heroes, there are real life subjects, it is a vibrating collective. It is very much like us. 


\section{Conflicting and resistant temporalities}

Paola: I think it is interesting to notice the temporalities in the movie. It took almost five years to be finished. In terms of commercial productions this is very long.

Bete: But during this period we had the coup. The initial idea had to be adapted to the call for projects, so that the proposal would fit the call that was out during Temer's government ${ }^{2}$. Then Bolsonaro was elected. The gestation of the movie is very much the gestation of the struggle. This gestation suffers the influences of the project calls, the political and economic conjuncture. It may have taken long time, but Camila can also tell you that it was like courting. Maybe if the process had been finished in a short period of time, we would not have had the time to get to know each other well. There is the film director's dynamic but there is also the dynamic of the militant subject. For example, if the movie had been produced faster, Camila would not have had access to many of the scenes. Our collective narrative was being constructed in the film production. In these four years we have had the time to understand how cinematography works, understand the dynamics of our internal organization. In this historical context Chão couldn't only be a movie about the Landless people; it had to be turned into a tool for grassroots work, a tool to counteract the hegemonic narrative about us. I don't see these four years as a very long time, because when we were shooting, it felt as though our time was different, sometimes very hurried, sometimes slower, this is the collective creative process. For example, when you see Granny, one of the characters, talking about her experience presenting the movie, not as a promoter of a product, but as subject, you can see how this collective construction of the movie can be transformative. We need to meet more Camilas, and encounter our communication, because we construct in cooperation, but sometimes we don't have the space. And also because of the rhythm of our daily lives we don't have the ideal conditions to take care of our communication.

2. Michel Temer was Dilma Rousseff's VP, who came to power after the impeachment in 2016 and led an interim government until the 2018 elections. 
Camila: It was a gestational post-production process, with all material that we had and all the angles that we could have given to the story. We were conscious that we would never reach a totality because a totality in two hours would have been very shallow. The horizontality of the construction is intimately related with the idea of intellectual emancipation that is present in all instances of the movement. It is an appropriation of narratives, the construction of auto-narratives. For example, we made a point to include all the meetings, to speak about this organizational process in which the peasants inform themselves and face very complicated legal issues. The lawyer is going to assist, but he is not going to decide, the people involved in the issue are going to decide. And this happens with all questions that are part of the struggle and will be appropriated by the people, regardless of their level of formal education. The subjective diversity is something that came along during the process. I started to realize that it was very interesting to observe the popular leaders. Oftentimes, I wanted to film leadership meetings and they slammed the door in my face, with all reason! I started to realize that this would put people at an unnecessary risk. Later I understood that it was just as interesting to see how these discussions and decisions taken behind closed doors reflected on the political sphere, on people at the grassroots, they also take decisions all the time. When we privilege these other aspects, we can reach other publics. If we remained on a very combative representation we would only reach a very specific public: the supporters, ourselves. I think this was an intuitive option and also very influenced by the political scenario at the time.

\section{Writing the world}

Paola: I would like to continue on this discussion about community communication. We usually say that the process, as you describe, is much more important than the results in community communication. Can you tell us what you have learnt in this process of media production? 
Luiz: There are two different dynamics here that we have to identify. The first one is MST's internal dynamics. In this effort to construct an outward message to society, the movement created the Sem-Terra newspaper ${ }^{3}$. Beyond attracting supporters outside the Movement who are making communication with the Movement and about the Movement, we have advanced a lot in the last twenty years in promoting the socialization of the means of production of media and culture. Our members, our militants, we Landless are also producers of content. This is not an instrumentalization of communication, and the process is key to create cohesion among our communities, in occupations and settlements: to establish a radio station, a newspaper and all these tools to create a dialogue with society. This is very important because we are a national movement in a country of continental dimensions, so we have differences between the states. In a state like Goiás we face limitations in the construction of this organizational process of our communication. But in many other states there are collectives of popular communicators that have achieved a very advanced technical and conceptual level in popular communication.

Another communication dynamic is the networks of supporters, friends, and collaborators that we construct along the way, and Chão is included in this dynamic. The originality of the film lies exactly in this idea that the production process is embedded in the struggle. The sincerity that you see in the scenes, in the expressions of our families, the settings that are not staged, are a result of the fact that the film is part of the daily struggle in Goiás. It is very difficult to achieve this, because when Camila arrived, she made this first bold movement going there with a camera, two, three friends and no funding. However, it was not only her move, but also a move from the part of the Movement, to create a dialogue with the Movement. What was going to be filmed, what was not going to be filmed, where the camera was going to be and where it was not going to be. The initial move was very important. The second move that was important in this collective construction is that when you create a movie, I suppose, you have a plot in your head, and you have the structures that are going to form this plot. Camila had this idea of a territorial film that would tell the story of the struggle for land in that

3. Jornal Sem-Terra is MST's newspaper, published since the beginning of the 1980s and distributed in the settlements and occupations. The newspaper was discontinued in 2015 and brought back into publication in 2019 as special issues with less frequent periodicity. 
territory, in a perspective that would include some people but without isolating or individualizing the struggle in a few characters. The construction of the film through time showed that this was not possible. The dynamic of the struggle for land cannot be controlled. Even without a coup, even without Bolsonaro's government or Temer's government, it would have been very difficult to gain the right to that land for any of those families. So, in order to make a film like this, the director must be very convinced that it is this collective process that will give meaning to the film. Of course, you must have a guiding idea in your head, but Camila arrived, and we began a dialogue and a process of comradery. By the end of the process she had about two hundred hours of footage without having a clear structure for the movie. Because she spent these years participating not only at Dom Tomás occupation, but in settlement processes, in other occupations. She was living the daily struggle for land. I think this is a very important element to understand how we can collaborate, from a position outside the organization, but participating as an insider in a process coordinated by an organization that engages in a struggle that is larger than the elements and questions with which you are dealing.

\section{Constructing relationships}

Camila: What Luiz and Bete said is very interesting, this process of constructing trust. All I have been seen and hearing about the film reflects this construction. Almost every time we show the film someone asks: "How come people are so comfortable in front of the camera?". And it is as Luiz says, there is no secret other than to understand that we were not Landless, we would not become Landless, but being part of this process and trying to represent the Movement in film, we had to flow with the struggle, and of course we would need to live, eat, be with people in the Movement, sleep in the tent, position ourselves as subjects of the struggle somehow. When we film an occupation, we are occupying land together with MST. We did not start the process but still we are bodies occupying a collective space and this process is much bigger than we are, bigger than what we are doing and even bigger than the film. It is a process of dimensions that surpass us as individuals. The first year of researching and filming this occupation process at Fazenda Santa Monica that we are discussing here is what allowed the collaboration and initiated 
what the film became later. Even despite many images from that time not making it into the movie. Chão could not be about that specific territory because the focus of the film gradually shifted to MST's struggle for land, and the struggle does not belong in only one territory. Then we had to first understand our place and our responsibilities as a film crew in this flow, in this struggle.

We went through this process of understanding our position there, because we were not there as tourists. After a while people treated us as anyone else from the Movement. I now realize that we only achieved this effect that the public tends to notice, this acceptance for the camera, because we were very present there. And still our presence was accepted after a long period, after much collective construction. We felt that we were performing a function, not just portraying something. At least it was a strong preoccupation to try to do this in a non-extractive form, because cinema can be extractive. You go there and capture what the other does. In the Movement we do not have the space for this attitude because someone who is just looking will be left out. When push comes to shove, when things must happen, when there is a heated conflict, you either have a function or you are a nuisance. I felt this very much with the function that the camera performed in the Mato Grosso occupation that we show at the end of the film, when the media reacts to our presence. There is that reporter that acts for the camera, he is clearly considering the presence of our camera. And there was the aspect of body positioning that was important, because we positioned ourselves on the Movement's side of the cordon. This conferred a particular function to the presence of our camera, and I think it is there in the film. When people are in their homes living their lives and we are there, they are also acting, but not in the sense of lying or falsifying something because all those scenes were constructed thinking with them. There was a very intense collaboration in the construction of each scene. This was the only way in which we could make something more consistent than if we were on the position of an observer. What I have learnt the most is that you come with your expectations because you are mobilising a team, using public resources and many other things, so I had to imagine that I would have a product at the end.

I got there with this idea to make a movie about that territory and was interested in peasants who had returned to the countryside from the urban peripheries. I wanted to make a film about this, about grassroots work, about people who had a 
past as peasants and were returning, reclaiming the land through the Movement. But reality is more complex than our scripts. The struggle at Dom Tomás became much more complex: there were two evictions, some people went to the north of Goiás and were quite isolated at places where things went into a standstill. Many of those I started following in the beginning gave up on the struggle, others moved. What remained strong was my initial connection with those who were in the leadership in coordinating functions. I had to listen to these people a lot, I abused their patience with many requests because I could not and did not want to go ahead without them. When this first script was dismantled I had to redo everything, and then they told me: "Look, MST"s focus in Goiás is now the land at Santa Helena Mill, in the south, there is a very interesting occupation there, things are flowing, people are there and are very resilient, go there and take a look". They sent me to many places, and I went to many places. There are hours of footage of things that have nothing to do with the film because I kept trying. Until I arrived at Santa Helena and the leadership and members of the movement embraced the movie and this process, we communicated and continued this process of constructing trust there, other characters entered the story. I understand now that this was the most mature stage of the process, it is the phase that shaped how the film turned out in the end.

When we arrived at Santa Helena, our process as a film-crew in collaboration with the Movement was much more advanced and I knew much better what I wanted. I had understood that I was making a movie about the territory, the ground, but it was not only one territory, because that is not how the Movement sees it. It is not only this land here, or that land there because unfortunately the whole national territory is permeated by irregularities, inequality and concentration of land. We developed the film there in its last phase. As if this whole process from 2014 until the beginning of 2017 had been a long experiment, a rehearsal. In 2017 we filmed during the whole year, mostly at Santa Helena. We had time with the people there, it is the place where we spent most time and things were really happening and that is why the film concentrates there. But I tried my best to make a final cut that would reflect the Movement's principle that agrarian reform is a broad long-term struggle, it is not localized at specific places, the struggle is a spirit. 
Image 2

Occupation of politician Blairo Maggi's farm

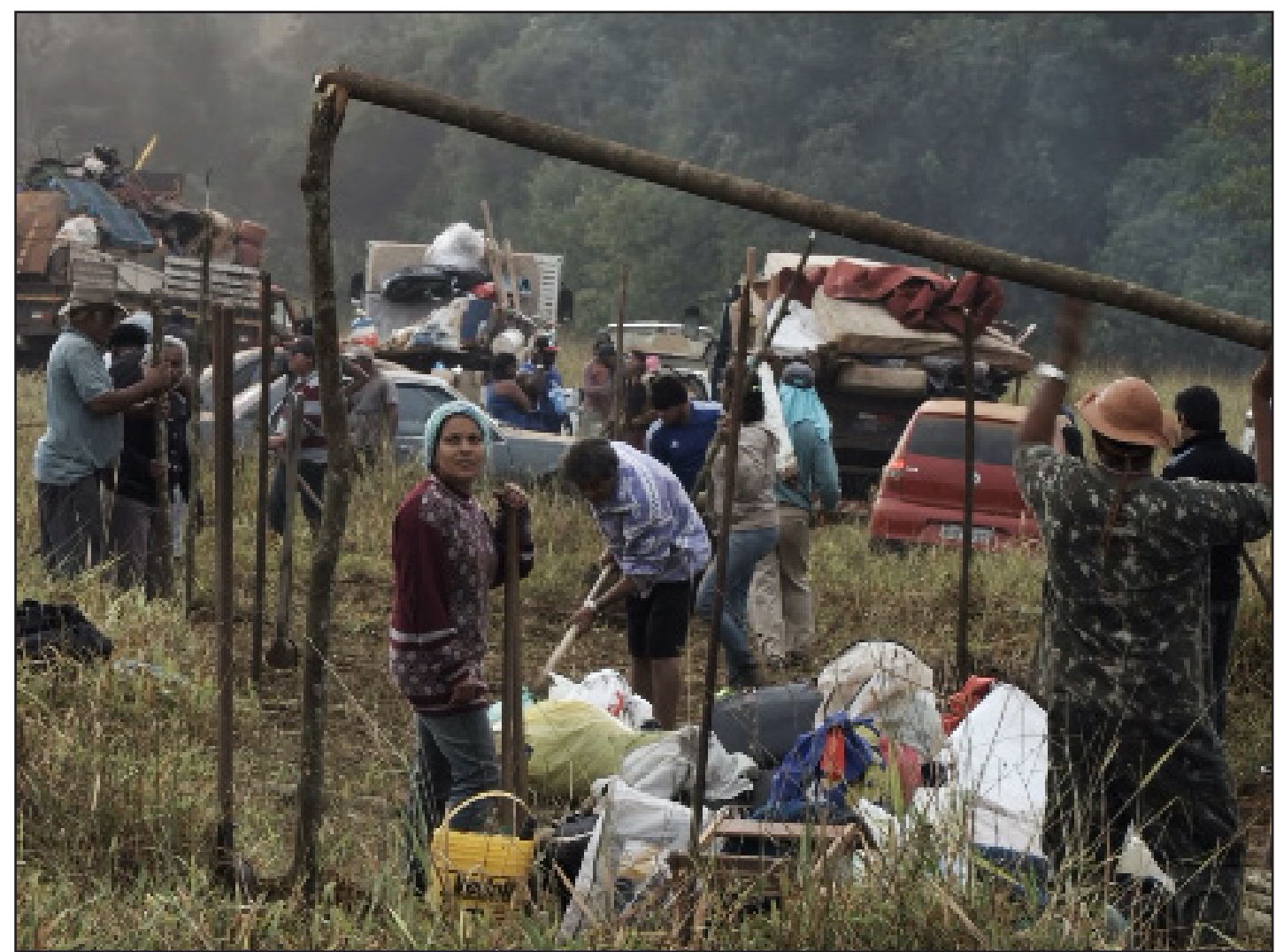

Photography: Camila Freitas

\section{Making mobilization visible}

Paola: Let us bring our discussion to Europe. I want to know about your hopes and goals when Chão is travelling around the world and you cannot control how it will be received. What can be the benefit for the Movement from this kind of dissemination?

Bete: My experience is that there were people who had never heard about MST and were shocked to know that it exists in Brazil. Some people knew the movement but not very deeply and others told us right up that we were crazy. They told us that the film is a political pamphlet and that we were opening the doors of our internal organizational processes to surveillance and repression. 
Had it been a fast production process, Camila would probably not have had access to meetings that are shown, because we would not have trusted her, she was not part of the process. But I believe that we succeeded in putting forward a narrative in which the Movement is not romanticized. It is possible to understand that the process of struggle for land many times does not have a happy end, the struggle is a continuous process. I felt very comfortable in the spaces where I presented the film in my role as militant in the Movement. It may be that it was the right moment. Bolsonaro had just started his mandate and there was much solidarity from people in general who had heard his violent statements about MST. People wanted to listen to us. This was important because we could say to the world after Bolsonaro's election that he cannot just decide that he will end our struggle because we have inherited it and it is going to last. The agrarian question in Brazil is not going to be solved in a couple of years.

Luiz: Just as we said that Camila faced difficulties because she came with an idea that was gradually transformed, I think it is important to recognize the objectives that we had in the leadership of the movement at the time. The film is a collective construction in which we always tried not to curb Camila's creative freedom. Our main goal was to give visibility to the necessity and urgency of agrarian reform. How could we show and present this to society? Focusing on the elements of popular agrarian reform, which is MST's most recent theoretical formulation. Popular agrarian reform goes beyond redistribution of land, to include the principle that this land must produce healthy food. This was our goal, to give visibility to this project in a process for the masses. The occupation Dom Tomás was a city, Santa Helena an even bigger city. How do we go, in the middle of a recession, in 20142015, from six hundred to seven thousand families living in occupations? Not considering those who left the occupation. We can say that we mobilized nearly twelve thousand people in the struggle for land in a three years period. We wanted to back up the claim that agrarian reform in central Brazil is urgent because that area is the belly of the agribusiness beast. 


\section{Dynamics of world-writing}

Luiz: During the process through which we constructed the film, as it happens in the process of the struggle for land, other things came up. And here I think the film brings some important elements. The first is that Chão portrays very well how shared understandings in the Movement are horizontally constructed. More than showing the MST's strength in this respect the movie fulfils this role of showing that all processes within MST have the Landless subjects as agents. It is not an ideological conspiracy to make a revolution and overtake power. It is a just struggle for the regularization of the constitutional right to land for those who want to work on the land. The second element is the subjective diversity of the Landless subjects. The film shows the Pentecostal Landless and the process, full of contradictions, of Landless LGBT subject construction. The movie shows the process to understand what the state is, what the judiciary power is, and what the media represent about the daily struggle of the families. Now, with a film, a book, an article... we cannot control what they are going to generate. Any of our films, any film about MST will never represent the totality of the movement, this is not even the point. It should not be the epic of an organisation. In a film you can also explore the contradictions because a popular organization is full of contradictions. We cannot control the impact of the movie on people, otherwise it would become a pamphlet, and this is not the idea. The idea is that the film would convey some messages: the struggle for land is alive, it is necessary, and it is urgent in Brazil. And there are new elements in the struggle for land in Brazil beyond the distribution of land, such as agroecology, the ways in which the families organize collectively, and the subjectivities of these families.

Camila: We finished editing during the election, when Bolsonaro was being elected. We had to find a balance at many points, say the same things in different ways so that the film would be accepted and not prevented from circulating. I think my expectations are being met in this respect. I am positively surprised with the ways people are receiving the film in very diverse places. I think that this micropolitical dimension can touch virtually anyone. This is what we have been noticing when the movie is shown in militant circles within MST and when it is shown in Berlin or many other places where we have been. The response is much along the lines of emphasizing the subjective aspects that construct the 
struggle. Of course, we also have this aspect of control, which is impossible. We do not have yet a wide response from the Brazilian public because we were going to release the film in commercial cinemas on Monday [23/03/20], but because of the pandemic everything is suspended.

We have had very good responses at screenings in national and international festivals, and criticism as well of course. Many people will say that the film is a pamphlet, but the positive responses outdo this criticism. In truth I think that the more the film is appropriated by MST, by other organizations, by schools, by researchers in other countries, the best. When we talk about someone else's film, someone else's process, we are going to leave our imprint, these are different perspectives and I think that it is an addition. I do not have the least pretension that I am going to follow all the exhibitions of Chão, because fortunately there have been many. It often happens that someone from MST presents the movie, if it is not me, someone from the crew, or all of us together. In the next months we were going to many places, Mexico, Guatemala, around Brazil. I hope we will be able to go to these places later because we can only benefit from the film being discussed from different perspectives. I think that this is how the film can make a contribution, creating networks of support for MST's struggle, which is a historical process.

Luiz: In reality we can say that this year of dissemination was a bit like tests inside bubbles. The commercial release is what is really going to show us the impact of the documentary in Brazil from the viewpoint that Bete mentioned. I am not excluding the possibility that parts of the film can be used by bolsominions ${ }^{4}$, generating a negative reaction. But we are also going to see what the average Brazilians, those who do not frequent film festivals, make of the movie. For us, internally in the Movement, this is a reason for anxiety.

4. Pejorative word that describes President Jair Bolsonaro's supporters. 


\section{Media and conscientization: reflections on the use and appropriation of media}

Paola: I wanted to bring up some scenes in the movie, those showing the media and journalists, and also a scene in the evening. It is dark and Bete tells people not to use their mobile phones during the act of occupation. You stress that people should protect themselves and switch off their phones. I would like to know your thoughts about these different media and these different ways to communicate. Why were these scenes included in the film?

Bete: First we have to make clear that media in Brazil are extremely biased. Media companies are the property of powerful families and they produce a hegemonic narrative criminalizing the struggle for land, particularly when it comes to MST and when MST is involved. When you refer to the journalists in the occupation, the film portrayed the reality. These are the journalists we have. One of them says that he is being threatened by an armed woman. You can only laugh at that, because it is ridiculous. And the other one was acting for Camila's camera, because it is obvious that he realized that he was being filmed. This is the media we have in Brazil, totally susceptible to co-optation. They have a ready-made narrative; they are going to distort whatever we say, and we will end up in the crime reporting, or they will say that we were blocking the traffic. This is what happens when they cover demonstrations, particularly when MST is present. They are not going to show our claims, the questions we are bringing up, they will say that we are blocking the traffic.

In Brazil communication does not aim for transformation, or to inform, quite the opposite. The media promote disinformation, a disservice. In that scene in particular, we were not forbidding people to use their mobiles. In that moment, to keep our safety, we were not going to use mobile phones, also because of strategic matters. Because if you film and it leaks, it can help our enemies and not us. We also have a task force, people who are in charge of communication. The communication teams exist in the states and nationally to help us bypass the media filters. We know that they are not going to talk about us. Then we have 
Brasil de Fato, Jornalistas Livres, Mídia Ninja. We manage to have this niche of outlets that help us break through the media filters and disseminate our views and our positions in the political struggles.

In these moments it is evident that everyone becomes quite euphoric. When they are concretely fighting for their rights, adrenaline goes up, you are there doing something as an active subject, and many times people will want to film, take pictures, post on the social networks, in media that will not make any impact. There is also a preoccupation because in this recent period we suffered with this process of criminalization in Goiás. Information posted on social networks was used to incriminate us. It is the art of war: when we are in the trenches, we need to double our guard. These scenes portraying communication and security measures always generate debate. I made that part in which a girl is sitting down, and the reporter says that she is threatening with a stick. The ability of the media to create anti-struggle and anti-demonstration content is enormous!

Luiz: We consider this point a sensitive one. It was not only the production process, the caption of images that was collective, but also the editing process. The film is more than a director's production. It is a film about a collective and in certain countries, in periods of repression we need to take collective care. It is important to stress this point in the production process: that we have to edit carefully. It is not a matter of censorship, but to protect popular organizations in countries like Brazil. We have evaluated that this mobile phone scene has a pedagogical importance. For us in the Movement it is becoming clearer that mobile phones are not a communication tool, they are a tool for control and manipulation of society. What Bete is saying is very clear. In an attempt to frame MST in Goiás as a criminal organization one of our main leaders, Valdir, was in prison for six months and the trial was constructed exclusively using Facebook posts. So that is how we understand the role of mobile phones to monitor, control and manipulate society. And regarding mainstream media, there are two points of connection in the film. At Vitória's tent when she is watching a commercial about agribusiness with Camila and Bento.

Bete: The commercial says: "There is a whole farm inside my fridge". 
Luiz: Yes, and the image is a bit faded, a bit blurry. And the next time is when the media appear in a low-quality television message, showing the news feature when they covered the protest. This low quality of the TV images has a very strong symbology, representing how distorted mainstream media coverage is. I think that in that moment, during the occupation, the film shows a more nuanced image because two supposedly different forms of journalistic coverage are presented, giving a fairer representation of the relation between commercial media and the Movement. We considered the whole block that addresses the relation with the media very important.

Camila: There is also this historical struggle, since the beginning of MST, for visibility. You mentioned Jornal Sem-Terra, that was born out of this need for communication and to produce a fair image of the movement against a strong tendency towards marginalization and production of stereotypes by the mainstream media that has historically represented MST as these criminals, terrorists, a social disturbance. We found ourselves exactly in this moment when the president was echoing this discourse in a completely irresponsible way and winning votes with it, openly saying that he was going to classify MST as a terrorist organization. In this sense, I think this scene with Bete is pedagogical, because people need to see the other side, how the Movement responds. Within MST there is a strong consciousness about the Movement's image, including the negative image that is disseminated. And this particular scene connects with an earlier scene when a TV agribusiness propaganda claims that the agribusiness produces food for Brazilian people. It is this dispute of narratives in which the agribusiness has much more visibility because they also control commercial media and the National Congress that makes laws. So the least MST militants can do is to protect themselves. It is very little but significant, to care about how communication tools are used so that they will not have these tools turned against them, which happens all the time.

\section{Prefiguring research possibilities}

Paola: Camila said something about extractive film, we also use this term in social movements research. Extractive research is when researchers contact social movements, collect material in form of interviews, data, and publish articles 
without constructing knowledge with the movement. In this sense I want to know more about your relationship with research and what you expect from researchers that are in contact with the MST, researching about and with the Movement.

Luiz: In the last few years, we have been thinking about it and we consider that it is important that researchers do not stop completely, but decrease the research about MST, about dynamics in MST settlements, and produce instead knowledge about how the capital is organizing in new forms, in different dimensions of life. This has to do with what Camila said and I think it is very important: how can you, as a researcher, a filmmaker, without being organic in the Movement, construct a process together with the Movement? You must understand that you will have tasks and responsibilities. It is not about returning the final product to the Movement, but about the construction of this product and how it contributes in its varied construction processes with tactical movements in specific moments.

From the point of view of social research, in geography, sociology, we have been indicating that it is important to understand these new ways in which capital appropriates of nature. From the point of view of natural and agricultural sciences we need to find ways to improve and disseminate the access to technology so that we can make advances in agroecology in our settlements. Research can of course identify agroecological practices in settlements and occupations, but we also need to make advances in agroecological techniques. We are not proposing a unilateral subordination to the Movement, but that researchers position themselves in a process of collective construction that is bilateral, to which researchers can bring knowledge from other processes and engage in collective construction with the organization.

In that moment when Camila was making the film, the Movement's need was to expose how the struggle for land was unfolding in Goiás. In this sense, her contribution as director was to transform the film into something different from what it would be if someone from MST's leadership had made it. But this exchange cannot happen only when the work is completed. The Movement allows researchers to enter our territories, provide data and you only come back in the end to discuss the results? Absolutely not! The processes to produce knowledge or art must be entirely collective and must be relevant to the dynamic of the struggle. 
Bete: In this historical period, we obviously need to know about what we are doing that is working to counteract the hegemony of capital, but we are also keen to know about our enemies. And not only from external researchers, but also from ourselves as researchers. Because within the movement, thanks to continuous education, state programmes for education in agrarian reform areas, there are many PhDs, people with master degrees and specialised in many questions.

Camila: I completely agree, but I just wanted to say that in my experience I do not know how it would be to make such a film in a long process about enemies, about a group with which I completely disagree, it would be very difficult. Many people do that, and I think it is important to portray the enemy, but in the case of Chão we were able to live in this exchange of experiences that Bete mentioned. People in there are specializing and deepening their knowledge on everything they are doing. We have, for example, PC, Granny, who are in the film and participate in MST's production sector and are studying different ways to grow crops, different ways to use land. There are also people who are working with legal issues and facing this world that is usually so hostile to the working class. If you come to do research, you must be open to the fact that you are not going to know all that happens in that place. You need to have certain flexibility and be willing to learn a lot. Even if I did not want to, it would not have been possible for me not to learn and rethink all I had imagined about the Movement, and I think this makes research richer. To search for the unseen images, the fissures, what is not in the newspapers, what is not going to appear in the media and that is not present in all that has already been made. This seems to be what motivates me the most. 


\section{Biographies}

\section{Elisabet Cerqueira da Conceição}

MST national coordination (Brazil)

ORCID: 0000-0002-8644-7836

elizapubli@gmail.com

Teacher and popular communicator from Bahia. Militant in MST since 2014 in the state of Goiás. Member in MST's education collective where she oversees educational activities for children, youth and adults in MST's settlemetns and occupied areas.

\section{Luiz Enrique Gomes de Moura}

MST national coordination (Brazil)

ORCID: 0000-0001-6077-6714

zarref@gmail.com

Luiz comes from a peasant family in the state of Goiás and was born in Taguatinga, DF. He holds a PhD in Geography and is a militant in MST since 2002, participating in the sector for Production, Cooperation and Enviroment in Goiás and in MST's national coordination and overseeing enviromental questions in the settlements, the advancement of agribusiness in Brazil and the implementation of public policies in these areas. 


\section{Camila Freitas}

Graduate Programme in Visual Arts, UFRJ (Brazil )

ORCID: 0000-0002-5963-8944

camilasfreitas@gmail.com

Filmmaker and photography director with a degree in Film Studies from the Fluminense Federal University in Brazil and specialization in photography direction at Louis Lumière School in Paris. Camila is currently a master student in Visual Arts at Rio de Janeiro Federal University. "Landless" is her first long film, it premiered in the 69th Berlin Film Festival and featured in many international and national festivals winning a number of prizes.

\section{Paola Sartoretto}

Jönköping University (Sweden)

ORCID: 0000-0002-5638-6606

paola.sartoretto@ju.se

Researcher and educator in Media and Communication Studies at Jönköping University, Sweden where she teaches in the Master Programme in Sustainable Communication. Paola has carried out an ethographic study of communicative processes within MST and has published extensively about the interplay between communication and political mobilization. 